$1-1-1930$

\title{
Relationship Between the Number and Weight of Eggs and Body Weight of Leghorn Fowls During the First Three Years of Production
}

Horace Atwood

T. B. Clark

Follow this and additional works at: https://researchrepository.wvu.edu/ wv_agricultural_and_forestry_experiment_station_bulletins

\section{Digital Commons Citation}

Atwood, Horace and Clark, T. B., "Relationship Between the Number and Weight of Eggs and Body Weight of Leghorn Fowls During the First Three Years of Production" (1930). West Virginia Agricultural and Forestry Experiment Station Bulletins. 233.

https://researchrepository.wvu.edu/wv_agricultural_and_forestry_experiment_station_bulletins/234 @ WVU. It has been accepted for inclusion in West Virginia Agricultural and Forestry Experiment Station Bulletins by an authorized administrator of The Research Repository @ WVU. For more information, please contact ian.harmon@mail.wvu.edu. 
West Virginia University Libraries

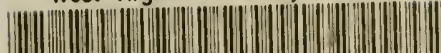

|.|.|. |.

308021008961191 


\section{West Virginia University Library}

This book is due on the date indicated below.

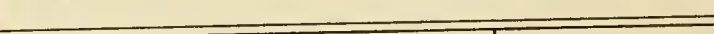


Digitized by the Internet Archive in 2010 with funding from

Lyrasis Members and Sloan Foundation 
The Relationship between the Number and Weight of Eggs and Body Weight of Leghorn Fowls during the First Three Years of Production

by HORACE ATWOOD and T. B. CLARK 


\section{AGRICULTURAL EXPERIMENT STATION STAFF}

JOHN R. TURNER, Ph. D., LL. D............. President of the University

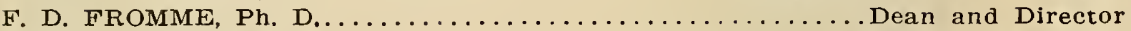

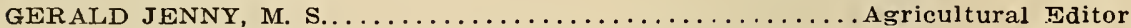
JOHN C. JOHNSTON.................................... Chief Clerk

\section{AGRONOMY AND GENETICS}

R. J. Garber, Ph. D.

Agronomist and Geneticist

E. P. Deatrick, Ph. D. Associate Agronomist

W. H. Fierre, Ph. D. Associate Agronomist

T. C. MeIlvaine, Ph. D. $\dagger$ Assistant Agronomist

D. R. Dodd, B. S., f

M. M. Hoover, M. S. Assistant Agronomist Assistant Agronomist

H. K. Rowley, M. S. Agr.** Seed Analyst

\section{A NIMAL HUSBANDRY}

E. A. Livesay, D. Sc. Animal lzusbandman

Chas. V. Wilson. M. S. Assistant Animal Husbandman

J. H. Longwell, M. A. Assistant Animal Husbandman

J. H. Rietz, D. V. M. Associate Veterinarian

R. H. Tuckwiller, B. S. Agr.* Assistant Animal Husbandman

R. S. Glasscock, M. S.** Assistant in Veterinary Science

\section{CHEMISTRY}

R. B. Dustman, Ph. D

Agricultural Chemist Chas. E. Weakley, Jr., B. A.

L. P. Hansen, Ph. D Assistant Chemist

T. B. Leith, M. S.** Assistant Chemist Assistant Chemist Leland Shriver, M. S. Ch. E. Assistant in Agricultural Chemistry

DAIRY HUSBANDRY

H. O. Henderson, Ph. D.

Dairy Husbandman

T. M. Thurston, Ph. D. Assistant Dairy Husbandman

K S Morrow, M. S. Assistant Dairy Husbandman

I. F. Sutton, B. S. Agr. $\div$ Assistant Dairy Husbandman

R. A. Ackerman, B. S. Assistant in Dairy Husbandry

\section{ENTOMOLOGY}

L. M. Peairs, Ph. D.

W. E. Rumsey, B. S.**

Entomologist State Fntomologist Edwin Gould, B. S. Agr. Assistant in Entomology FARM ECONOMICS

A. J. Dadisman, $\mathrm{Ph}, \mathrm{D}$.

Farm Economist

F. I. Cornell, Jr., M. S. Assistant Farm Mechanician

W. W. Armentrout, M. S. Assistant Farm Economist

R. O. Stelzer, B. S. Assistant in Farm Economics

HOME ECONOMICS

Rachel H. Colwell, M. A.

Home Eiconomist

Hazel C. Cameron, M. A. Research Specialist in Nutrition

\section{HOR'TICULTURE}

H. E. Knowlton, Ph. D

I. C. Westover, M. S. Agr. Assistant Horticulturist

F. W. Craig, M. S. Agr.**

M. B. Hoffman, M. S. Assistant Horticulturist Assistant in Horticulture

E. N. McCubbin, M. A. Assistant in Forticulture

A. P. Dye, M. S. Agr. Assistant in Horticulture

\section{PLANT PATHOLOGY}

C. R. Orton, Ph. D.

Plant Pathologist

Anthony Berg, M. S. Associate Plant Pathologist

L. H. Leonian, Ph. D. Associate Plant Pathologist

F. J. Schneiderhan, M. S. Associate Plant Pathologist

E. C. Sherwood, M. S. Assistant Plant Pathologist

\section{POULTRT HUSBANDRY}

Horace Atwood, M. S. Agr. Poultry Husbandman

T. B. Clark, B. S. Agr. Assistant in Poultry Husbandry

*In cooperation with the U. S. Department of Agriculture, Washington, D. C. † In charge of the Lakin Sub-Station, Lakin, W. Va.

tResigned, February, 1930.

* In cooperation with the State Department of Agricultire, Charleston, W. Va.

t In charge of the Reyniann Memorial Farms, Wardensvilie, W. Va. 


\section{The Relationship between the Number and Weight of Eggs and Body Weight of Leghorn Fowls during the First Three Years of Production*}

by HORACE ATWOOD and T. B. CLARK

$\mathrm{T}$

HE INCREASING importance of the poultry industry demands more definite knowledge than is now available concerning the normal variation in the fecunclity of fowls at different ages and the changes taking place in the weight of the eggs and in the weight of the fowls from year to rear. This bulietin is intended as a contribution on this subject, and in addition there is considered (1) the number and weight of the eggs laid by a bird as influenced by the weight of the bird: (2) the relationship between the number of eggs laid by a bird and the weight of the eggs; (3) the relationship between early sexual maturity and the fecundity of the birds at different ages.

In discussing the results of this investigation it has been the enleavor of the authors to interpret the finclings so as to afford new viewpoints from which future progress may be made. $\dagger$

\section{CONDITIONS OF THE EXPERIMENT}

The present experiment was begun in 1925 with 200 Single-Comb White Leghorn pullets. The results for the first year have been discussed in Bulletin 220 of this Station in which it is reported that fowls were fed a uniform ration from year to year. Each bird was weighe:1 once each month. They were trapped and the weight of each egg was recorded to one-tenth gram. At the end of the first year the birds were transferred from the small colony houses in which the work was begun to a Missouri type laying house.

\section{Mortality and Health of Fowls}

During the first year 12 birds died, 10 being killed by dogs and two through disease. During the second year there were 10 mortalities and during the third year, 13. An infestation of worms occurred during the latter year. To remedy this an effertive vermifuge was administered. The infestation and subsequent treatment probably increased the mortality and reduced production somewhat for the year, but at no time was there an outbreak of an infections disease.

*Submitted for publication September, 1929 .

$\doteqdot$ Lse has been made of more than 72,000 numbers showing egg weights and more than 6,000 numbers shwwing bory weights. :s the basis of the report in this bulletin. 


\section{RESULTS OF THE EXPERIMENT}

The following discussion of results is based on the records made by 178 birds during the first and second years and by 165 birds which remained in the experiment at the end of the third year.

\section{Annual Egg Production as Influenced by Age of Birds}

Eyg Production for First Tu Years. The influence of senescence on egg production has received considerable attention from poultry investigators. Jull (19:28) has summarized the restults of 25 experiments in which data are presented showing the number of eggs laid by various breeds during the first two years of production. In these experiments there were 3,979 birds consisting of 540 Barred Plymouth Rocks, 811 Rhode Island Reds, 230 Wyandottes, and 2,398 Leghorns. If the results of two of the experiments, in which the egg production for the second year of 87 fowls appears to be greater than for the first year, be disregarded, then the unweighted average egg production for the first year is 195.09, and for the second year 14C.08, or a decrease due to senescence of 26.1 percent. It was observed that the higiner the production the first year, the greater the decrease the second year, and that the average decrease in the production of the general purpose breeds for the second year was somewhat greater than in the case of the Leghorns.

Egg Production for First Three Yeurs. Ball, Alder. and Egbert (1916) found the following average production of eggs for the first is years of selected flocks whose records were available:

\begin{tabular}{|c|c|c|c|}
\hline & $E g$ & Product & \\
\hline Type of Fowl & lear: First & second & Third \\
\hline Leghorns _. & 180 & 146 & 119 \\
\hline General purpose breeds & 177 & 11.6 & 93 \\
\hline $\begin{array}{l}\text { Decrease in production of Leghorns } \\
\text { (percent) }\end{array}$ & & 19 & 18 \\
\hline $\begin{array}{l}\text { Decrease in production of general purpose } \\
\text { breeds (percent) }\end{array}$ & & 34 & 20 \\
\hline
\end{tabular}

It may be observed that the decrease in egg production from the first to the second year as given by Ball, Alder, and Egbert is in reasonably close agreement with the figures as given by Jull when consideration is given to the fact that Jull's summary is based on flocks of which 60 percent were Leghorns and 40 percent general purpose breeds.

\section{Influence of Senescence}

The mean egg production of the White Leghorns in the present experiment during the first 3 years of the test was as follows:

\begin{tabular}{|c|c|c|c|}
\hline Eggs laid & $\begin{array}{c}\text { First } \\
170.219 \pm 2.039\end{array}$ & $\begin{array}{c}\text { Tear of Test } \\
\text { Second } \\
135.978 \pm 1.875\end{array}$ & $\begin{array}{c}\text { Third } \\
106.151 \pm 1.891\end{array}$ \\
\hline Decrease & & $34.241 \pm 2.770$ & $29.827 \pm 2.663$ \\
\hline Decrease (percent) - & & 20 & 22 \\
\hline
\end{tabular}


These results agree closely with the results for Leghorns as summarized by Rall. Alder, and Eghert. It mas be conchurled that monder usual commercial conditions the decrease in egg production with I.eghorus will be about 20 percent per year.

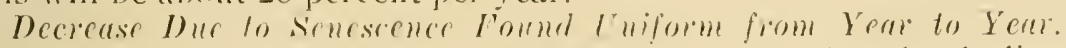
Brody, Hendersom, and Kempster (19:21) have shown that the decline in egg production with age is a fairly comstant perceniage of the precerling year's production. These authurs suggest that it is not the number of owytes in the hen that linits joroduction but rather the decline in vigor of some limiting organ or organs, and that this decline in vigor follows the course of a simple chemical reaction.

\section{Factors Affecting Weight of Eggs}

little systematic work has been done by poultry in estigators to cletermine the amount of fluctuations or the various causes which bring about such fluctuations in the rieight of the eggs of the domestic fowl. It is well known that in some breeds of poultry certain individuals lay larger eggs than others, and that pullet eggs gradually increase in size as the birds grow older. The sentor anthor has shown (19:6) that an mbalanced ration fed to laying hens may decrease the exgr weight by as much as 12 percent. He has also shown (19.23) that if chicks are fed during the eariy stages of their growth so that they are permanently stunted, then the eggs which they may lay later will be smaller than if the birds had been fed a ration permitting them to attain a normal size. It is also known (19:23) that there is a seasonal variation in the weight of eggs, the eggs being smaller in summer and heavier in fall and winter. The senior anthor has also shown (1918) that the first eggs of a crcle are usually heavier than the eggs lairl later in the same cycle. From these considerations it is evident that the weight of an egg at any particular time is the resultant of various hereditary and environmental factors.

Changes in Egg Weight Due to Senescence. Table 1 shows the average weight of the eggs laid during each month of the 3 years, the total weight of the eggs for each month, the average weight of the eggs for each year, and the weight of the eggs laid per bird per year. This table show's that the average weight of the eggs laid during the first or pullet year was $53.24 \pm .16$ grams, and that the weight for the second year was $56.87 \pm .17$ grams, an increase of $3.6 .3 \pm .23$ grams, or 6.8 percent. There was no significant change from the second to the third year in the average weight of the eggs, showing that in this case the normal weight of the eggs for the mature fowls was arrived at during the second year of production.

The weight of the eggs produced per bird during the first year was 9,029 grams and for the second year 7,726 grams, a decrease, due largely to senescence, of 1,303 grams, or $1+.+$ percent. The decrease for the third year as compared with the second was 1,7is grams, or 22.2 percent. It is evident thereiore that the decrease in total egg substance due to advancing age accompanies decrease in egg number. 


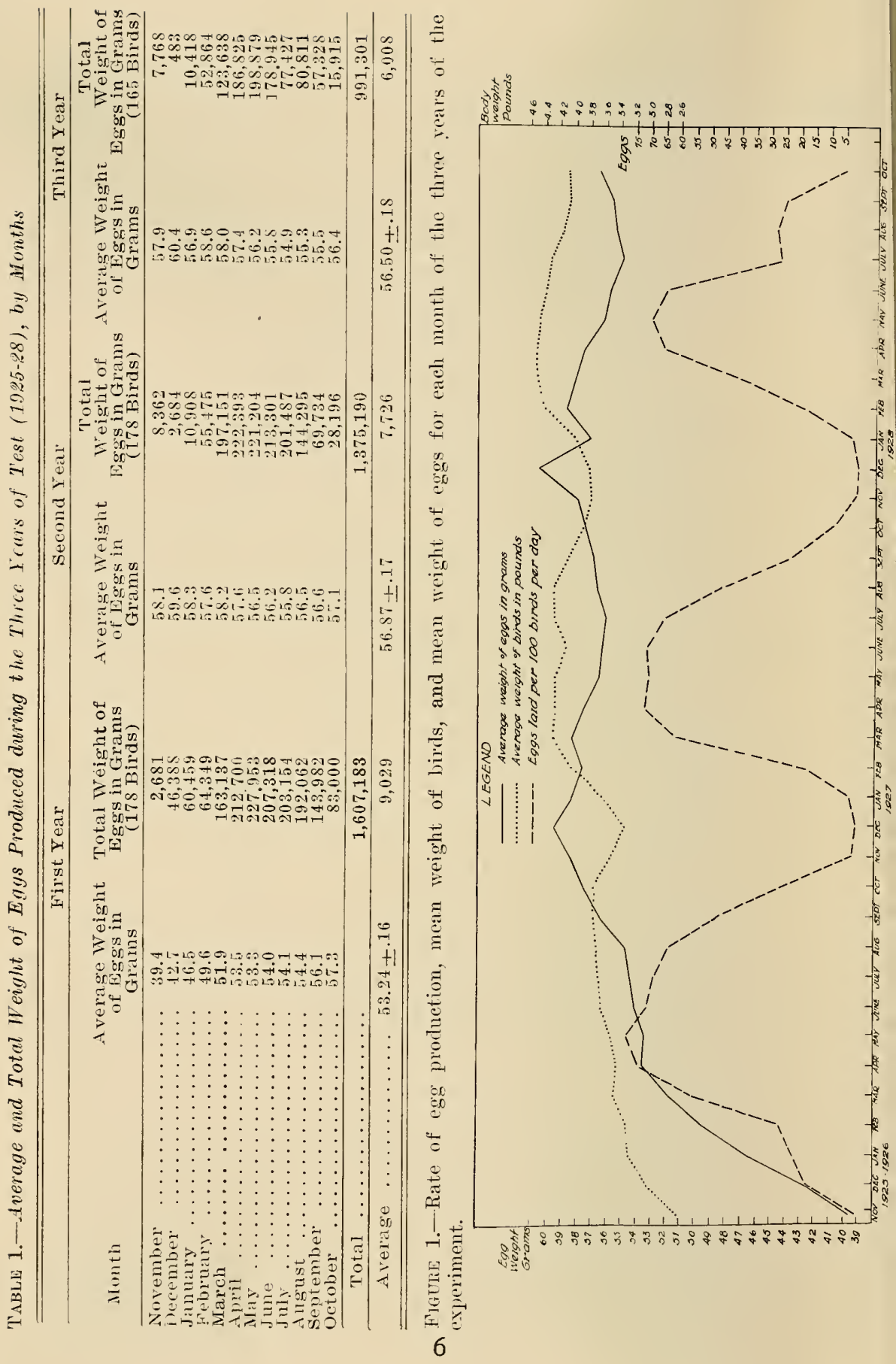




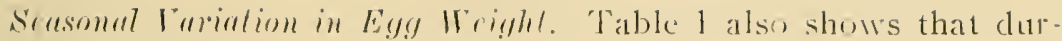
ing the first lear of the trial the weighi of the eggs increased with consiclerable regularity from the ninimum of 39.4 grams in November to the maximum of 57.3 wams durine the following October. This increase in cgg weight during the pullet rear, paralleling the increase in body weight, is entirely dissimilar to the distribution of egg weight during the two following years. During these two later years the mininum egg weight occurs in the hot summer months, and the maxinnum weight during late fall or at the beginning of winter, when egg production is at low ebb.

This distribution of egg weight agrees with earlier findings of the senior author (19.23), who found that in goneral, and especially after the pullet year. the greater the number of eggs laid during a month, the smaller they tend to become during that month. Experiments by Hadley (1919), whose results were hased primarily on the pullet year, seemed to indicate that increased production is accompanied by increased mean weight of the eggs. Undoubtedly this sitnation nay arise when the increased production is bronght about by changing to a better ration, or when it is accompanied by an increase in the mean weight of the birds as during the pullet year. The evidence on hand, however, shows that with a uniform ration and with mature fowls, increased production is usually accompanied by a decreased mean egg weight.

If the tendency toward decreased egg weight, which is brought about by increased production, could be overcome by more skillfu? feeding or otherwise. it might result in maintaining egg production for a longer time at a high level. Decreased egg weight under these circumstances may indicate that the ration may not supply sufficient digestible nutrients or may not be sufficiently concentrated for the use of the birds under the conditions of maximum production.

\section{Seasonal Influence on Egg Production}

Table 2 shows the total number of exgs and the rate of production for each month of the 3 years.

The minimum rate of production for the pullets occurred in November, when they first began to lay, and the maximum rate in May, when they laid at the rate of $78.6 \mathrm{eggs}$ per clay per 100 birds. From this peak, production decreased gradually until the end of the first laying year. During the two following years the minimum rate of production was in December, while the heariest production occurred in April for the second year and in May for the third year.

During all 3 years the heaviest production occurred during the months of April, May, and June. The rate of production during these months did not vary much during any year. The minimum production was during November, December, and January and it seems entirely probable that, in any effort to increase the production of the birds in West Virginia, the conditions affecting egg production during these 3 months should receive first attention. Under commercial 
TABLE 2.- Vumber of Eggs Produced and Tote of Laying daring the Three Terurs of Test, by Months

\begin{tabular}{|c|c|c|c|c|c|c|}
\hline \multirow[b]{2}{*}{ Month } & \multicolumn{2}{|c|}{ First Year } & \multicolumn{2}{|c|}{ Second Year } & \multicolumn{2}{|c|}{ Third Year } \\
\hline & 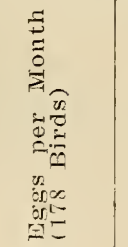 & 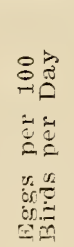 & 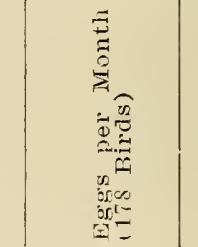 & 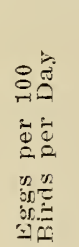 & 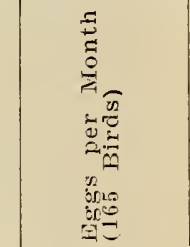 & 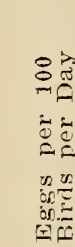 \\
\hline 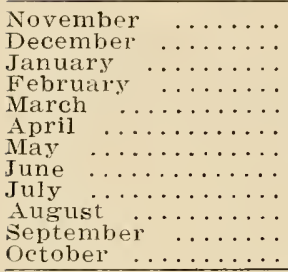 & $\begin{array}{r}68 \\
1086 \\
1301 \\
1298 \\
3145 \\
3975 \\
4275 \\
3842 \\
8758 \\
3582 \\
2565 \\
1449 \\
\end{array}$ & $\begin{array}{r}1.27 \\
19.68 \\
23.58 \\
26.04 \\
27.00 \\
74.48 \\
78.60 \\
71.95 \\
65.11 \\
64.01 \\
+8.03 \\
26.26 \\
\end{array}$ & $\begin{array}{r}144 \\
45 \\
18 \\
963 \\
3389 \\
3864 \\
3916 \\
3793 \\
3608 \\
2552 \\
1232 \\
494 \\
\end{array}$ & $\begin{array}{r}2.70 \\
.82 \\
3.39 \\
18.66 \\
61.42 \\
72.36 \\
70.97 \\
71.03 \\
65.39 \\
46.25 \\
2.3 .07 \\
3.95 \\
\end{array}$ & $\begin{array}{r}134 \\
8 \\
183 \\
901 \\
21: 11 \\
3250 \\
3535 \\
3205 \\
1410 \\
1460 \\
1032 \\
282 \\
\end{array}$ & $\begin{array}{r}2.71 \\
.16 \\
3.57 \\
18.83 \\
41.66 \\
65.66 \\
69.11 \\
64.74 \\
27.57 \\
28.54 \\
20.85 \\
5.51 \\
\end{array}$ \\
\hline Total $\ldots \ldots \ldots$ & 0,296 & & 24,187 & & 17,531 & \\
\hline Average ... 170 & 2 per yedr & 46.63 & 135.9 per year & 27.23 & 106.2 per year & 29.03 \\
\hline
\end{tabular}

conditions reliance is now placed on pullets to supply eggs during this period of low production, but it should be possible to shorten considerably this period by breeding for a shorter moult, or perhaps by feeding a more concentrated or more stimulating ration.

\section{Body Weight}

Table 3 shows the mean body weights of the birds for each month of the 3 years. This table shows that during the pullet year the weight of the birds increased with a fair degree of regularity from the beginning of the year to its close. The most rapid gain in weight was during the month of November, with an increase of almost one-half pound per bird. The monthly changes in weight were small, but the tendency to become heavier with increasing age is apparent.

TABLE 3.-Average Body Ileirht of Birds for the Three Irars by Months

\begin{tabular}{|c|c|c|c|}
\hline Month & First Year & Second Year & Third Year \\
\hline 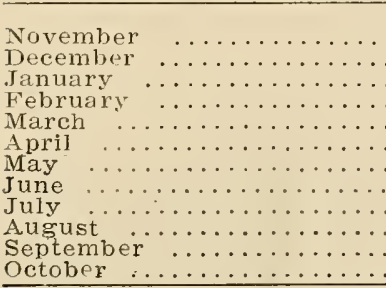 & 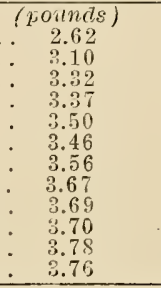 & $\begin{array}{c}\text { (1.0unds) } \\
3.5 .8 \\
3.37 \\
3.62 \\
4.02 \\
4.27 \\
4.23 \\
4.22 \\
4.12 \\
4.25 \\
4.27 \\
4.11 \\
3.82 \\
\end{array}$ & $\begin{array}{c}\text { (polnels) } \\
3.80 \\
3.82 \\
4.01 \\
4.41 \\
4.56 \\
4.57 \\
4.49 \\
4.40 \\
4.35 \\
4.19 \\
4.14 \\
4.15 \\
\end{array}$ \\
\hline Average $\ldots \ldots \ldots \ldots \ldots$ & $3.46 \pm .01$ & $3.99 \pm .02$ & $4.25 \pm .02$ \\
\hline
\end{tabular}


During the second year the minimmm weight was noted on the first of December. A fairly uniform increase in weight followed until the first of March. When the weight declined slightly until the first of June. The average weight for the second year was slightly more than one-half pound greater than during the pullet year, or an increase of 15.3 percent.

During the third year the birds were lightest in weight on the first of November and heaviest in March and April. The mean weight of the birds was about one-fourth pound greater than during the second year. After the puliet year there was a strong tendency for the weight to decrease during October, November, and December, or dining the period of lowest egg production. It seems possibie that if the live weight conld be maintained at a higher level during those months it might have a beneficial effect on the egg production at that time.*

The rate of egg production, the mean weight of the birds, and the mean weight of the eggs for each month of the 3 years are shown in Figure 1 on page 6.

\section{Standard Deviations and Yearly Correlations in Egg Production}

The mean egg production per bird for each of the 3 years and the standard deviation in the number of eggs are shown in the following schedule :

\begin{tabular}{|c|c|c|}
\hline & Egg Pioduction & Stundard Devintion \\
\hline Fir: & $170.219 \div 2.039$ & $40.326 \pm 1.442$ \\
\hline ond year & $135.97 \mathrm{~s} \pm 1.875$ & $37.076 \pm 1.325$ \\
\hline hird year & $106.151 \div 1.891$ & $35.988 \pm 1.336$ \\
\hline
\end{tabular}

The correlations based on the production of the 165 birds remaining at the end of the third year are the following:

Correlation between production of first and second $\mathrm{y} \in$ ars: $r=+.4 i 3 \pm .041$ Correlation between production of first and third years: $r=+.357 \pm .046$ Correlation between production of second and third years: $r=+.561 \pm .033$

The mean egg production as influenced by the age of the birds has been discussed in this publication. The standard deviation in the number of eggs laid was somewhat less in the case of the older fowls. This agrees with earlier findings of the senior anthor (19:6). During all 3 years the deviation was high, indicating a high degree of variability in the population.

The correlation in the egg production from one year to another was significant in all cases, showing that on the average a reasonably good layer the first year would probably be a reasonably good layer during the second and third years. This relationship, however, is not. marked, showing that with a particular bird various other factors besides heredity are involved in determining the number of eggs lair from year to year.

*This mattor should be investiguted further. 


\section{Standard Deviations and Yearly Correlations in Egg Weight}

The mean weight of the eggs for each year and the standard deviations in the weight for the 3 years are shown in the following schedule. The constants for the first two years are based on the production of the 178 birds remaining in the test at the end of the second year, and for the third year on the production of the 165 birds remaining at the end of that year.

\begin{tabular}{|c|c|c|}
\hline 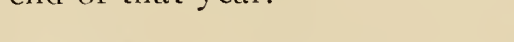 & Wean Egg Weight & Standard Deviation \\
\hline Fins & $53.244 \pm .166$ grams & $3.276 \pm .117$ \\
\hline Second year & $56.876 \pm .171$ grams & $3.386 \pm .121$ \\
\hline Third year & $56.506 \pm .180 \mathrm{grams}$ & $3.438 \pm .129$ \\
\hline
\end{tabular}

The correlations of the mean egg weights for each bird for the different years were found to be as follows:

Correlation in mean egg weight between first and second

years: -

Correlation in mean egg weight between second and third

years:

$\mathrm{r}=+.903 \pm .010$

This is a high degree of correlation and shows that the characteristic egg weight for a bird is a relatively stable character, persisting from year to year. The uniformity in the standard deviation for the 3 years indicates that there was no change in variability in the weight of the eggs due to senescence or other factors.

\section{Standard Deviations and Yearly Correlations in Body Weight}

The mean weight of the birds for each year, the standard deviation in weight, and the coefficient of variation for the three-year period are shown below:

\begin{tabular}{|c|c|c|c|}
\hline & Mean Body II eight & Standard Deviation & $\begin{array}{c}\text { Coefficient of } \\
\text { Tariction }\end{array}$ \\
\hline First year & $3.46 \overline{5} \pm .014$ pounds & .227 - .010 & $6.55 \pm .45$ \\
\hline Second year _..._- & $3.996 \pm .019$ pounds & $.374 \pm .013$ & $9.35 \pm .78$ \\
\hline Third year _...... & $4.256 \pm .022$ pounds & $.429 \div .016$ & $10.08 \div .92$ \\
\hline
\end{tabular}

The correlation between the body weights for the first and second years was: $r=+.827 \pm .016$, and for the second and third years: $r=$ $+.918 \pm .008$. These coefficients show a high degree of continuity in the relative body weights from year to year.

The coefficients of variation, which became larger as the birds became older, indicate a greater variability 111 the weight of the birds with increasing age. This may be because the poorer layers take on more weight with increasing age than is the case with the better layers.

To test this suggestion the coefficients of correlation were calculated between the increase in the body weight from the first to the third year and (1) the egg production for the first year; (2) the production for the third year; and (3) the decrease in the production from the first to the third year. The results are shown below: (Cf. Tables 2 and 3.) 
Increase in mean boty weight for the third year as compared with the first year, and egg produc-

tion during the first year _..................

Do. and egg production during third year $\ldots \ldots \ldots \ldots . . .129 \pm .051$

Do. and decrease in eggs laid during third year as

comparerl with tirst year

Mean increase in weight from first to third year_._ $19.787 \pm .014$ pounds

Standard deviation of increase in weight $\ldots \ldots \ldots . .258 \pm .010$

Mean llecrease in number of eggs trom first to

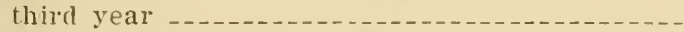

Standard deviation of decrease in egg production.-

$63.75 \pm 2.30$

$43.98 \pm 1.63$

The evidence show's that there is no connection between changes in body weight and egg production. A bird which has taken on extra weight during the third year is as likely to be a good layer as one that has remained lighter in weight.

\section{Correlations Between Body Weight and Egg Weight}

In 1925 the senior anthor ubserved that the heavier birds of a flock usually lay the heavier egys. The present investigation confirms the earlier findings. The correlations betw cen mean body weight and mean egg weight for the 3 years are as follows:

Egg weight for first year and borly weight for that year: $r=+.458 \pm .040$

Egg weight for second year and body weight for that year: $r=+.434 \underline{-t-.040}$

Egg weight for third year and body weight for that year: $r=+.426 \pm .043$

These coefficients are all positive and significant and indicate that the heavier birds lay the heavier eggs.

Working with 40 Barred Plimouth Rock pullets Jull (192x) found a positive correlation of .34t+.09+ between maximum body weight and mean egg weight for the year. 'This coefficient is in fairly close agreement with those reported above.

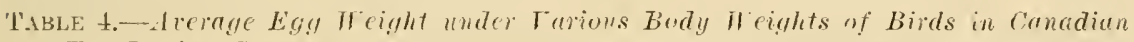
Egg-Laying Contests

\begin{tabular}{|c|c|c|c|c|c|c|}
\hline Body weight (Pounds) & 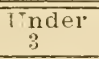 & $\begin{array}{l}3- \\
31 / 2 \\
\end{array}$ & $3 \frac{1 / 2-}{3 / 4}$ & $\begin{array}{c}3 \% / 4- \\
1 \\
\end{array}$ & $\begin{array}{l}1- \\
1 / 2 \\
1 / 2\end{array}$ & $\begin{array}{c}\text { Over } \\
4\end{array}$ \\
\hline $\begin{array}{l}\text { Average egg weight } \\
\text { (Ounces per dozen) } \\
\end{array}$ & 23.0 & 23.3 & 25.7 & 23.9 & 24.1 & 24.9 \\
\hline
\end{tabular}

In the Report of the Sixth, Seventh, and Eighth Annual Canadian National Egg-Laying Contests (19:9) the relationship between body weight and egg weight is considered, basing the conclusions on data obtained from 1,772 White Leghorns and 1,947 birds of the heavier breeds. Table 4 shows the relationship between body weight and egg weight for White Leghorn pullets in the Canadian contests.

There is a gradual increase in egg size as the body weight increases.- All evidence confirms the results of the present investigation and also that of the earlier work done at this Station. 
During the first year of the present investigation there was a progressive increase in the weight of the birds and also a similar increase in the weight of the eggs from month to month. The coefficient of correlation between the monthly weight of the birds and the monthly weight of the eggs was found to be +.996 \pm .013 .

Regulation of Egg Weight by Culling Undersized Pullets. The mean egg weight for the birds in the present investigation for the pullet year was found to be $53.2 \mathrm{grams}$, or $22 \mathrm{1} / 2$ ounces per dozen,- too low to meet the requirements for standard-size eggs. The question arises as to how the egg size could be increased quickly. From the evidence presented with reference to the relationship between body weight and egg weight it would seem that by rigid selection of the large, well-developed pullets the average egg size could be materially increased.

Table 5.-Percentage of Pullets of Different Body Weights in Each Class of Egg Weights, and Mean IVeight of Eggs Laid by the Puliets in Each Class

\begin{tabular}{|c|c|c|c|c|c|c|}
\hline \multirow{3}{*}{$\begin{array}{l}\text { Body Weight in Pounds } \\
\text { on Nov. 1, } 1925\end{array}$} & \multirow{3}{*}{$\begin{array}{l}\text { Number } \\
\text { of Birds }\end{array}$} & \multicolumn{4}{|c|}{ lercentage of Pullets in Each Class } & \multirow{3}{*}{$\begin{array}{l}\text { Mean } \\
\text { Weight } \\
\text { of Eggss } \\
\text { (grams) }\end{array}$} \\
\hline & & \multicolumn{4}{|c|}{$\begin{array}{c}\text { Average Weight of Eggs in Grams } \\
\text { during April, } 1926\end{array}$} & \\
\hline & & $\begin{array}{l}44 \text { to } 48 \\
\text { grams }\end{array}$ & $\begin{array}{c}49 \text { to } 53 \\
\text { grams }\end{array}$ & $\begin{array}{c}54 \text { to } 58 \\
\text { grams }\end{array}$ & $\begin{array}{l}59 \text { to } 63 \\
\text { grams }\end{array}$ & \\
\hline $\begin{array}{l}2.0 \text { to } 2.4 \\
2.5 \text { to } 2.9 \\
3.0 \text { to } 3.4\end{array}$ & $\begin{array}{r}13 \\
127 \\
14\end{array}$ & $\begin{array}{c}(\text { percent }) \\
16.2 \mathrm{~S} \\
2.36\end{array}$ & $\begin{array}{c}\text { (percent) } \\
53.49 \\
47.24 \\
33.71\end{array}$ & $\begin{array}{c}\text { (percent) } \\
23.25 \\
44.88 \\
64.28\end{array}$ & $\begin{array}{c}\text { (percent) } \\
6.98 \\
5.51\end{array}$ & $\begin{array}{l}51.8 \\
53.9 \\
54.9\end{array}$ \\
\hline
\end{tabular}

As indicated in Table 5, the pullets in the present experiment on November 1 of the pullet year were divided into three classes according to body weight. The table shows the mear weight of the eggs laid by the birds in the three classes and the percentage distribution of these eggs arranged in classes according to weight.

If the birds in the first class had been removed, constituting about 25 percent of the flock, virtually all of the birds laying eggs less than 22 ounces in weight per dozen would have been eliminated. Table 5 also shows that the large birds, those in the third class, laid eggs averaging slightly more than 3 grams heavier than the eggs laid by the birds in the first class.

From the above it is evident that through the remoral of the smaller pullets in the fall an appreciable nncrease can be attained in the average weight of the eggs laid by the fiock.

\section{Correlation Between Number and Mean Weight of Eggs}

It is generally assumed that the heavy layers of a flock have a tendency to lay eggs slightly sinaller than the average for that strain. If this is so, it might be possible in breeding for increased production to produce birds that would lay more eggs, but if these eggs are smaller there might be no improvement in the birds as producers of egg substance. Hence it is important to know whether there is any connection between the number of eggs that a hen may lay and the weight of these eggs. 
In 1923 the senior author reported correlations between the number of eggs laid and their mean weight as follows:

$\begin{array}{ccc}\text { Flock: } & \text { Number of Birds } & \text { Corrdations } \\ \text { A-pullets } & 24 & \mathrm{r}=+.41 \pm .11 \\ \text { B-pullets } & 24 & \mathrm{r}=+.26 \pm .13 \\ \text { C-pullets } & 20 & \mathrm{r}=+.19 \pm .14 \\ \text { D-pullets } & 20 & \mathrm{r}=+.22 \pm .14 \\ \text { A-yearlings } & 23 & \mathrm{r}=+.24 \pm .13 \\ \text { B-yearlings } & 21 & \mathrm{r}=+.03 \pm .15\end{array}$

None of these coefficients is significant, with possibly an exception in the case of Flock A pullets. During the second year of production in this flock the coefficient is not significant.

Jull (19:1) in reporting data from to pullets found no significant correlation between egg weight and production.

Parkhurst (19:25) in reporting data from 41 Leghorn pullets found that the coefficient of correlation between 365-day production and the mean weight of the eggs for the same period was: $r=-.1541 \pm-102 S$, which is not significant.

In 1925 the senior author reported correlations between the number of eggs laid by a bird in one year and the mean weight of the eggs as follows:

$\begin{array}{lc}\text { Flock } & \text { Year of Production } \\ \text { ACE } & \text { First } \\ \text { BDF } & \text { First } \\ \text { AC } & \text { Second } \\ \text { BD } & \text { Second } \\ \text { A } & \text { Third } \\ \text { B } & \text { Third }\end{array}$

Correlations
$\mathrm{r}=-.225 \pm .068$
$\mathrm{r}=+.177 \pm .069$
$\mathrm{r}=+.260 \pm .097$
$\mathrm{r}=-.021 \pm .107$
$\mathrm{r}=+.015 \pm .140$
$\mathrm{r}=-.287 \pm .135$

In this case three of the coefficients were positive and three negative. None, with the exception of Flock ACE for the first year, is significant.

In the present investigation the following results have been obtained:

Ycrr
1
2
3

Number of Birds
178
178
165

Coefficient of Correlation $\mathrm{r}=+.180 \pm .049$
$\mathrm{r}=+.052 \pm .050$

None of these coefficients is significant. The evidence at hand shows that there is no connection between the fecundity of a bird and the size of her eggs. Stated in other words, a heary layer is as likely to lay large eggs as small ones.

\section{Correlation between the Number of Eggs and Mean Weight of Birds}

Considerable work has been done by poultry investigators to determine the relationship between the weight of the body and the fecundity of fowls. Lewis, Hannas, and Wene (1919) studied the relationship between body weight and egg production with 556 Leg- 
horns in the Vineland Egg-Laying Competition. The coefficient of correlation as computed by Platt (192\%) was $+.0734 \pm .0285$. Sherwood (1922), using data from 128 Leghorns, reported a coefficient of correlation between the annual production and the body weight of the birds at the end of the laying year, of $+.009- \pm .060$. Hervey and Lewis (19:4), working with 80 Barred Rocks, fonnd a positive correlation between body weight and egg production of .1269 \pm .0742 . Jull in the same year with 40 Barred Rocks reported a negative correlation of -.114 \pm .093 between the maximum body weight of the birds and the annual production. Platt (192\%), using the data derived from the records of 435 Leghorns in the First International Egg-Laying Contest at Vineland, N. J., found the coefficient of correlation for the pullet year to be $-.0630 \pm .0322$, and for the yearling year, --.3314..0293.

The experiments referred to above indicate little if any connection between the weight of a bird and the number of eggs that she may lay, although Platt (192\%) drew the conclusion that White Leghorn pullets should attain a body weight of approximately 4 pounds before the winter of their first laying year, and that a body weight in excess of $41 / 2$ pounds during their yearling year would be detrimental to egg production.

TABLE 6.-Relationship Between Body Weight and Number of Eggs Laid by White Leghorns in Canadian Eng-Laying Contests

\begin{tabular}{|c|c|c|}
\hline Body Weight & Number of Birds & $\begin{array}{l}\text { Average Egg } \\
\text { Production }\end{array}$ \\
\hline $\begin{array}{l}\text { Under } 3 \text { lbs. } \\
3 \text { lbs. to } 3.51 \mathrm{bs} . \ldots \\
3.5 \text { lbs. to } 3.75 \text { lbs. } \\
3.75 \text { lbs. to } 4 \text { lbs. } \\
4 \text { lbs. to } 4.5 \text { lbs. } \\
4.5 \text { lbs. and above }\end{array}$ & $\begin{array}{lr}\ldots \ldots & 96 \\
\ldots \ldots & 314 \\
\ldots \ldots & 378 \\
\ldots \ldots & 425 \\
\ldots \ldots & 396\end{array}$ & $\begin{array}{l}137.9 \\
158.6 \\
179.1 \\
192.0 \\
200.9 \\
206.6\end{array}$ \\
\hline
\end{tabular}

In the Report of the Sixth, Seventh, and Eighth Annual Canadian National Egg-Laying Contests (1929) a comparison is made between the body weights and the egg production of 1,772 White Leghorns. A summary of the data is given in Table 6 . This table shows a very decided correlation between the weight of the White Leghorns in these contests and the average number of eggs laid. The relationship was slightly less marked in the case of the Barred Rocks, White Wyandottes, and Rhode Island Reds. The advice is given for Leghorn breeders to breed their birds well up to standard weight.

Results Obtained in the Present Erperiment. The coefficients of correlation between the mean body weights and the number of eggs produced were as follows:

Eggs laid first year and body weight same year: $\ldots \ldots-\ldots=+.106 \pm .050$

Eggs laid second year and body weight second year: $r=+.125 \pm .050$

Eggs laid third year and body weight third year: $\ldots . .-1=-.127 \pm .052$

None of these coefficients is significant, since they are only about twice as great as their probable errors. 'These results considered in connection with the results, reported above, disregarding for the 
monnent the results derived from the Fugr-Iaving Contests, strongly support the conclusion that there is no relationship between the body weight of Leghorns and the number of exgs which they may lay. In the case of the clata from the liggr-fayng Contests. whicls are in nuore or less direct disagreement with this conclusion, it should be pointed out that the birds in these contests were developed under very diverse conditions with reference to breeding and iceding, and nuquestionably sone of them were considerably younger than others when the contests began. Hence it appears that the body weights on which this correlation was based were influenced by the different ages of the birds, and the results as shown in Table 6 may indicate merely that the more mature and better developed birds laid better during their pullet year than their less mature and less well-dereloped and consequently smaller competitors.

\section{Correlation between Age at First Egg-Laying and Annual Production}

In a flock of pullets in which the birds are all of the same age. some will begin to lay considerably earlier in the fall than others. The question whether such individuals are better layers than those which reach sexual maturity more slowly has received consiclerable attention from poultry investigators.

Kempster (1925) in his bulletin on "The Correlation between Sexual Mlaturity and Egg Production" refers to the work of 11 other investigators and presents the results of 6 years' work at the Missouri Station.

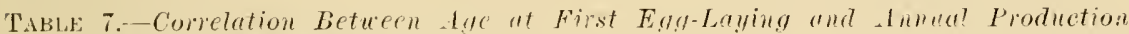
Found at the Missouri Station

\begin{tabular}{|c|c|c|c|c|}
\hline Yeat & $\begin{array}{c}\text { Number of } \\
\text { Brds }\end{array}$ & $\begin{array}{l}\text { Coefficitnt of } \\
\text { Correlation }\end{array}$ & $\begin{array}{l}\text { Mean Egg } \\
\text { Production }\end{array}$ & $\begin{array}{l}\text { Mean Days } \\
\text { To Mature }\end{array}$ \\
\hline $1917-18$ & 95 & $-.3182+.00 ?$ & $143.62 \pm 2.3 !$ & $232.76+2.0 t$ \\
\hline $1918-19$ & 133 & $-.4448 \pm .044$ & $151.16 \pm 2.03$ & $256.3 \div 1.97$ \\
\hline $1919-20$ & 152 & $-.2 S+6 \pm .051$ & $153.95 \pm 2.09$ & $198.34 \pm 1.52$ \\
\hline $1920-21$ & 237 & $-.422 S \pm .02 i$ & $148.83 \pm 1.65$ & $218.51 \div 1.46$ \\
\hline $1921-22$ & 152 & $-.363 \overline{1} \pm .048$ & $149.93-1-1.78$ & $249.67 \pm 1.70$ \\
\hline $1.922-23$ & 224 & $-.2339 \pm .043$ & $146.74 \pm 1.76$ & $232.7 \pm 1.50$ \\
\hline
\end{tabular}

Table 7 shows the correlation coefficients between the rate of maturity and the annual egg production as obtained at the Missouri Station. This table shows a significant negative correlation between rate of sexual maturity and ammal egg production for each of the 6 years. There also was found a still higher negative correlation between rate of sexual maturity and winter egg production. Hence the bircls which begin to lay earliest in the fall make better winter layers and lay better during the first or pullet year than the birds which mature more slowly.

It is important to know whether the superior production of the early maturing birds extends berond the pullet year. The present inrestigation is intended to shed some light on this question. The 
correlation cuefficients based on the 165 birds that finished the third year were as follows:

$$
\begin{aligned}
& \text { First year: }-.459 \pm .041 \\
& \text { Second year: }-.107 \pm .052 \\
& \text { Third year: }-.063 \pm .052
\end{aligned}
$$

The coefficient for the first year is negative and significant and agrees with the results obtained by Kempster and several other in-

\begin{tabular}{|c|c|c|c|}
\hline Character & Mean & $\begin{array}{l}\text { Standard } \\
\text { Deviation }\end{array}$ & $\begin{array}{l}\text { Coefficient } \\
\text { of Variability }\end{array}$ \\
\hline \multicolumn{4}{|l|}{ First year-178 birds } \\
\hline Egg production & $170.22 \pm 2.04$ & $40.38 \pm 1.44$ & $23.69 \pm 2.96$ \\
\hline Egg weight $\ldots \ldots \ldots \ldots$ & $53.24 \pm .17$ & $3.28 \pm .12$ & $6.16 \pm .29$ \\
\hline Body weight $\ldots \ldots \ldots \ldots$ & $3.46 \pm .01$ & $.2 s \pm .01$ & $8.01 \pm .43$ \\
\hline \multicolumn{4}{|l|}{ Second year-178 birds } \\
\hline Egg production ....... & $135.98 \pm 1.8 \mathrm{~s}$ & $37.08 \pm 1.33$ & $27.27 \pm 3.87$ \\
\hline Egg weight $\ldots \ldots \ldots \ldots$ & $56.88 \pm .17$ & $3.39 \pm .12$ & $5.96 \pm .28$ \\
\hline Body weight $\ldots \ldots \ldots \ldots$ & $3.99 \pm .02$ & $.37 \pm .01$ & $9.35 \pm .78$ \\
\hline \multicolumn{4}{|l|}{ Third year -165 birds } \\
\hline Egg production & $106.15 \pm 1.90$ & $35.99 \pm 1.3+$ & $33.90 \pm 5.92$ \\
\hline Egg weight ... & $56.51 \pm .1 .8$ & $3.44 \pm .13$ & $6.03 \pm .30$ \\
\hline Body weight..$\ldots \ldots$. & $4.28 \pm .02$ & $.43 \pm .02$ & $10.08 \pm .92$ \\
\hline
\end{tabular}

TABLE 8.-Constants Obtained for the First Three Fears in a Study of Certain Normal Characteristics of Thite Leghorn Females

\begin{tabular}{|c|c|c|c|c|}
\hline Characters & & Year & 178 Birds & 165 Birds \\
\hline Egg production & $\begin{array}{l}\text { Between } \\
\text { Between } \\
\text { Between } \\
\text { Between }\end{array}$ & $\begin{array}{l}\text { first and second } \\
\text { first and second } \\
\text { first and third } \\
\text { second and third }\end{array}$ & $r=-+.382 \pm .043$ & $\begin{aligned} \mathrm{r}= & +.473 \pm .041 \\
& +.357 \pm .016 \\
& +.561 \pm .036\end{aligned}$ \\
\hline Figg weight & $\begin{array}{l}\text { Between } \\
\text { Between }\end{array}$ & $\begin{array}{l}\text { first and second } \\
\text { second and third }\end{array}$ & $+.861 \pm .013$ & $\div .903 \pm .010$ \\
\hline Body weight & $\begin{array}{l}\text { Between } \\
\text { Between }\end{array}$ & $\begin{array}{l}\text { first and second } \\
\text { second and third }\end{array}$ & $+.827 \pm .016$ & $+.918 \pm .00 \mathrm{~s}$ \\
\hline Production and egg & weight & $\begin{array}{l}\text { First year } \\
\text { Second year } \\
\text { Third year }\end{array}$ & $\begin{array}{l}+.180 \pm .049 \\
+.052 \pm .050\end{array}$ & $-+.044 \pm .052$ \\
\hline Production and body & weight & $\begin{array}{l}\text { First year } \\
\text { Second year } \\
\text { Third year }\end{array}$ & $\begin{array}{l}+.106 \pm .050 \\
+.125 \pm .050\end{array}$ & $-.127 \pm .052$ \\
\hline Fge weight and body & y weight & $\begin{array}{l}\text { First year } \\
\text { Second year } \\
\text { Third vear }\end{array}$ & $\begin{array}{l}T .458 \pm .040 \\
+.434 \pm .040\end{array}$ & $+.426 \pm .043$ \\
\hline $\begin{array}{c}\text { lars maturing and } \\
\text { of egge latid }\end{array}$ & number & $\begin{array}{l}\text { First year } \\
\text { Second year } \\
\text { Third year }\end{array}$ & $\begin{array}{l}(188 \text { birds }) \\
-.403 \pm .041\end{array}$ & $\begin{array}{r}-.159 \pm .041 \\
-.107 \pm .052 \\
-.063 \pm .052\end{array}$ \\
\hline
\end{tabular}

TABLE 9.-Correlation Cotfficients Obtained betueen Certuin Normul Charateristies of White Legliorn Fcmales 
vestigators. but the confficients for the secombl and third years are not significant, and indicate that there is no connection between carly maturity and the number of eggs iaid during the seeond and third years.*

Tables 8. 9, and 10 bring together in convenient form for reference the principal means, deviations, and correlations fonnd in the present investigation.

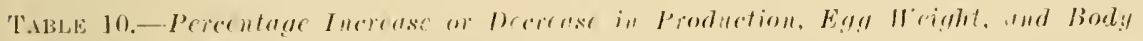
"leight of White Leghorn Frmales

\begin{tabular}{|c|c|c|c|}
\hline Chalucters & Decrease or Tncrease & Yeilr & Percent \\
\hline Nimber uf eges ploduecd & $\begin{array}{l}\text { Decrease } \\
\text { Decrease }\end{array}$ & $\begin{array}{l}\text { First to secomil } \\
\text { Second to thirel }\end{array}$ & $\begin{array}{l}20.12 \\
21.94\end{array}$ \\
\hline Meill ang weight & $\begin{array}{l}\text { Ducrease } \\
\text { Decrease }\end{array}$ & $\begin{array}{l}\text { Fisst } 10 \text { second } \\
\text { second to third }\end{array}$ & $\begin{array}{r}6.82 \\
.70\end{array}$ \\
\hline Boly weight & $\begin{array}{l}\text { Increase } \\
\text { Increase }\end{array}$ & $\begin{array}{l}\text { First to second } \\
\text { second to third }\end{array}$ & $\begin{array}{r}15.13 \\
6.26\end{array}$ \\
\hline Totill weight of eggs laid & $\begin{array}{l}\text { 1) crease } \\
\text { Decrease }\end{array}$ & $\begin{array}{l}\text { First to second } \\
\text { Secont to third }\end{array}$ & $\begin{array}{l}14.4 \\
22.25\end{array}$ \\
\hline
\end{tabular}

\section{SUMMARY AND CONCLUSIONS}

In this experiment the influence of senescence decreased the egg production from the first to the second year 20 percent, and from the second to the third, 22 percent. This result when considered in connection with the results of other investigations shows that when Leghorns are maintained under average conditions the decrease in egg production due to increasing age is, in round numbers, 20 percent per year.

The average weight of the eggs laid during the pullet year was $53.2+ \pm .16$ grams, during the second year, $56.87 \pm .17$ grams, and during the third vear, $56.50 \pm .18$ grams. There was no significant change in egg weight from the second to the third year, but from the first year to the second year there was an increase of 6.8 percent.

The average weight of the eggs laid per bird was 9,029 granis for the first year, 7.726 grams for the second year, and 6,008 grams for the third year. The decrease from the first to the second year was $1+. t$ percent and from the second to the third year, 22.2 percent.

During the pullet year the eggs increased in weight with a fair degree of uniformity from the beginning of the laying year to its close. During the two following years the heariest eggs were laid in December and the lightest eggs in July.

Egg prorluction was at its maximum intensity in April and May and at its lowest in November and December.

The average weight of the birds during the pullet year was 3.46 pounds, for the second year 3.99 pounds, and for the third year +.25 pounds. The increase in weight from the first to the second year was 15.3 percent and from the second th the third year. 6.52 percent.

* If this result should be conlirmed by later studies it will be helpful to determine why this relationship should wist hetwern early maturity and egg production during the first year and not later. 
During the pullet year the birds increased in weight with fair regularity from the beginning of the year to its close.

During the two following years the birds were lightest in weight during November and December and, in general, heaviest in March and April.

The correlations for the different years in the number of eggs laid per year were significant in all cases, showing that a reasonably good layer the first year would probably be a reasonably good layer during later years. The coefficients of correlation, however, are not large, showing that various factors are myolved in determining the number of eggs that a bird may lay from year to year.

The correlations for the different years in the mean annual egg weights were highly significant in all cases, showing that the weight of the eggs laid by a bird is a relatively stable character, persisting from year to year.

The coefficients of correlation between body weight and egg weight were significant in all cases, showing that the heavier birds laid the heavier eggs.

The birds became somewhat more variable in body weight as they became older, but there was no evidence to show that the birds which became materially heavier with increasing age were either better or poorer layers than their companions which remained lighter in weight.

The size of the eggs laid by a flock may be increased by culling out the smaller pullets in the fall.

There was no connection between the number of eggs laid by a bird and the mean weight of the eggs. A bird which lays a large number of eggs is as likely to lay large eggs as small ones.

There was no connection between the mean body weights of the birds and the number of eggs laid. A small puliet is as likely to lay a creditable number of eggs as her larger companion.

The younger the pullet when beginning to lay, the better the egg production for the pullet year. This relationship did not hold true cluring later years. 


\section{LITERATURE CITED}

ATWOOD, H., and WEAKl.EY, C. E., Jli.

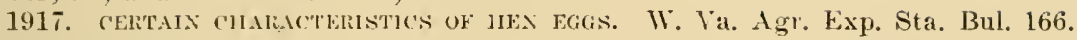
ATพOOD, H.

1923. INFLIFACE OF RATINS FED TO GROWING CHICKS ON TIE CILARACTERISTICS OF THE AルLT FEMALE. IV. Vi, Agr. Exp. Sta. Bul, 179.

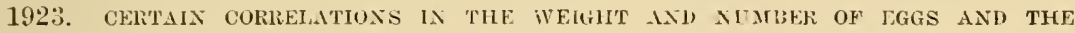
WEIGIT OF Fowis. W. Val. Agr. Exp. Sta. Bul. 182.

1925. TIE STANDARD IEVIATION IN THE WEIGILT OF WHITE LEGHOIN EGGS. W. Va. Agr. Exp. Sta. Bul. 195.

1926. SOME FACTONS AFFECTING 'THE WEIGHT OF EgGS. W. Va. Agr. Exp. Sta. Bul. 201.

B.ILL, E. D., ALDER, B., and FGBERT, A. D.

1916. BReEding for Egg production. Pali i. Utah Agr. Lxp. Sta. Bul. 148.

Brody, S., Hexdersox, E. W., aud Kempster, H. L.

1924. THE RATE OF SENESCENCE OF. TIE DOMESTIC FOWL AS MEASURED BY THE

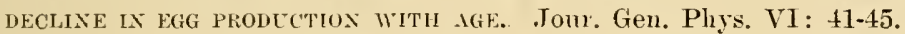

HADLET, P.

1919. EGG WEIGHT AS A ClITERIUN OF NUMERICAL PRONUCTION IN TIL DOMESTIC Fowl. Amer. Nat. LIII, Sept.-Oet. 1619.

Henves, G. W., and Lewis, H. R.

1924. THE RELATION OF EXTERAM BOHY CHARACTERS TO ANNEAL PHODUCTION IN B.ARRED PLIMOUTII ROCKS. Poult. Sci. III, 3.

JULL, M. A.

1924. egi Weight in Retation to pronction. Poult. Sci. III, 5.

192S. SECUKD YEAR EGG PRODUCTION IN REIATLON TO FIRST YEAR PRODUCTIOA IN the dunestic fowl. Poult. Sci. VIl, 6.

KFM PSTER, H. L.

1925. THE CORRELATION BETWEEN SEXUAL MATERITY AND EGG PRODUCTION. Mo. Agr. Exp. Sta. Res. Bul. 78 .

Lewis, H. R., H.xxis, R. R., and WExE, E. H.

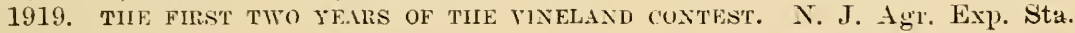
Bul. 338.

PARKHURT, R. T.

1926. CERTAIN FACTORS IN RELATION TO PRODUCTIOX AND EGG WEIGH'T IN WHTE 1.EGIIORNs. Poult. Sci. V, 3.

Platt, C. S.

1927. RELATIONSHIP BETWEE: BODY WEIGHT AND EGG PRODUCTION IN THE DOMESTIC FOWL. Poult. Sci. VI, 6.

REPORT OF THE SIXTH, SEVENTH, AND EIGHTH ANNUAL CANADIAN NATIONAL EGG-LAYLNG CONTESTS.

1929. Dominion of Canada, Dept. of Agr. Bul. 180 (new series).

SHERWOOD, R. II.

1922. CORRELATION BETWEEN EXTERNAL BODY CHARACTERS AND ANNUAL EGG PRODUCTION IN WHITE LEGHORN FUWLS, Texas Agr. Exp. Sta. Bul. 295. 
AGRICULTURAL EXPERIMENT STATION

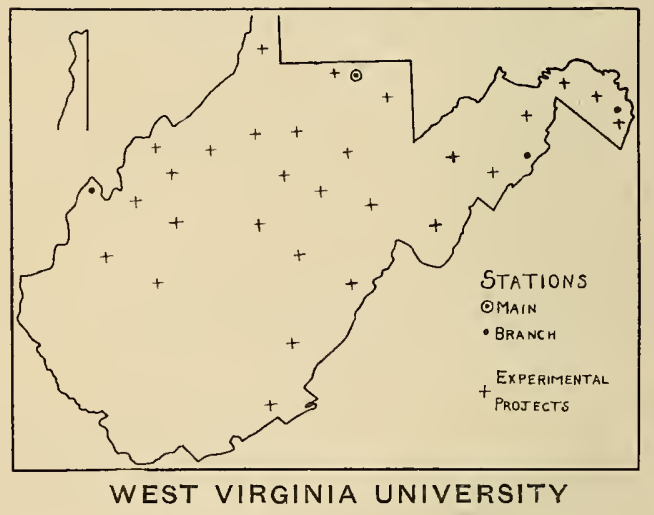





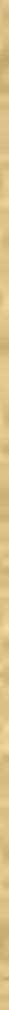

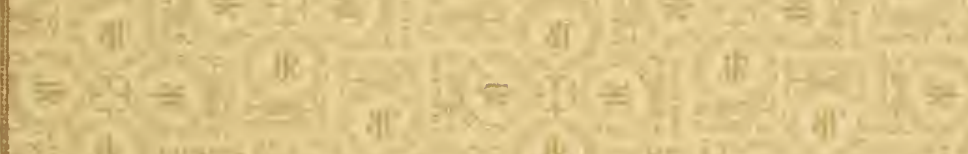

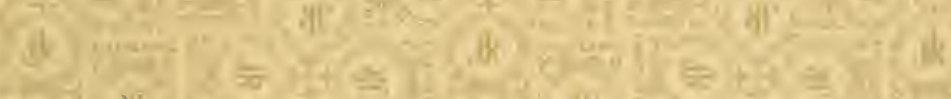

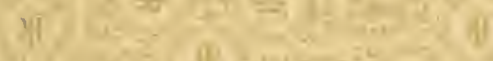

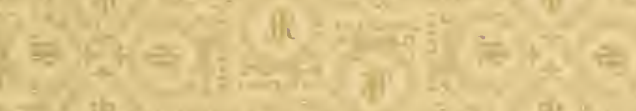

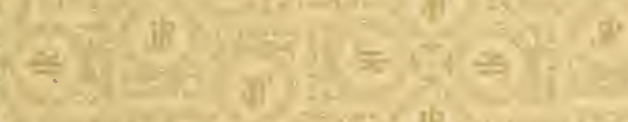

1

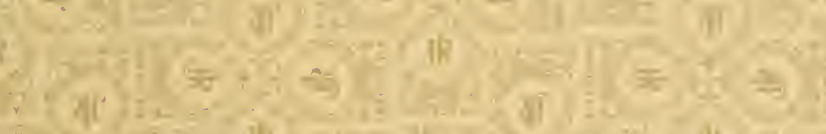

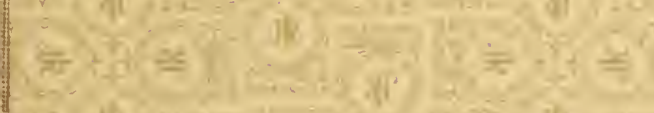

Xe. 1,2

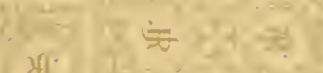

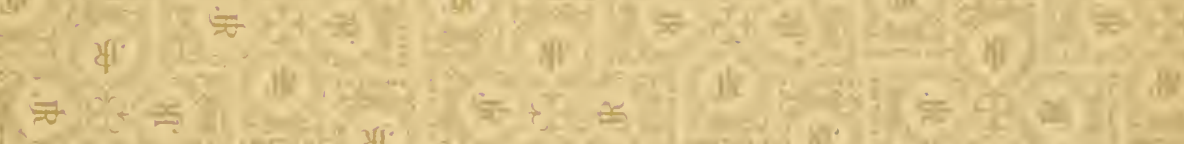

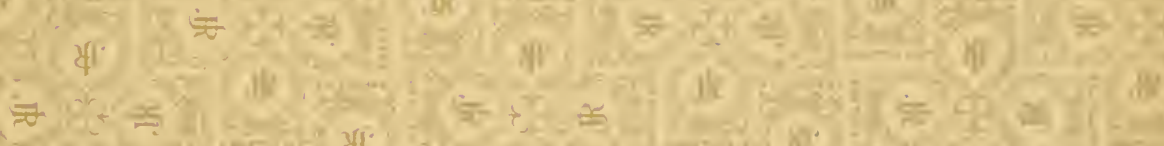

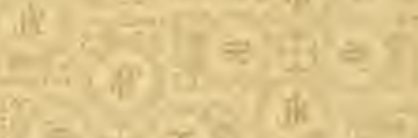

71

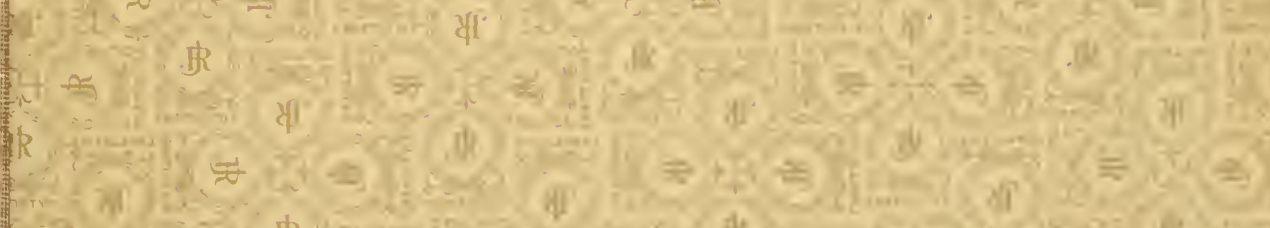

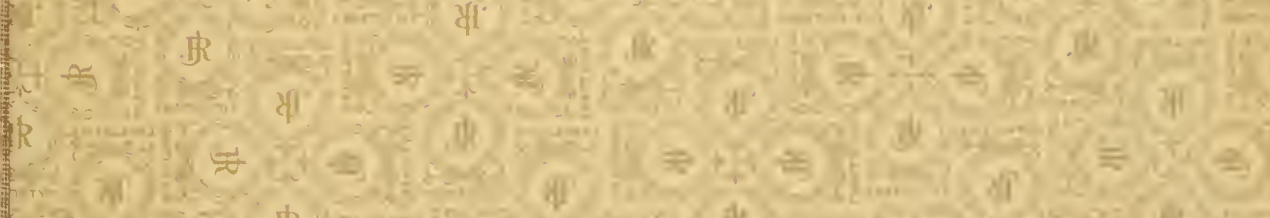

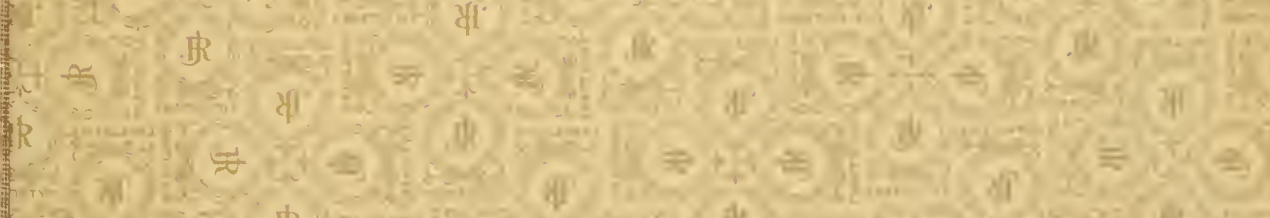

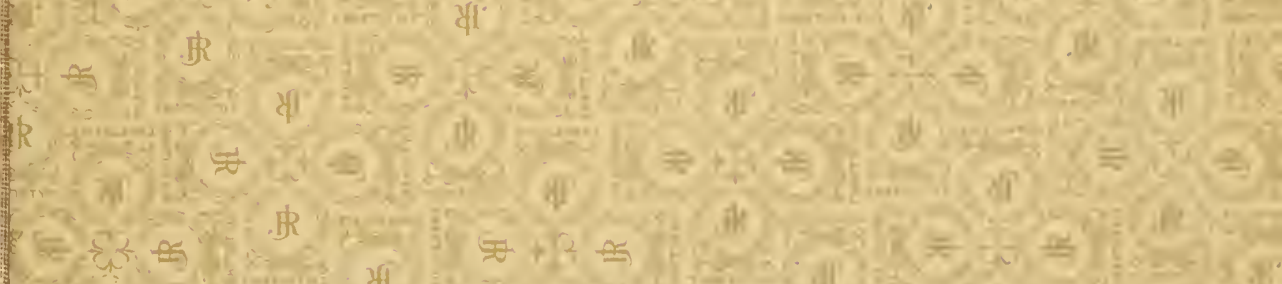

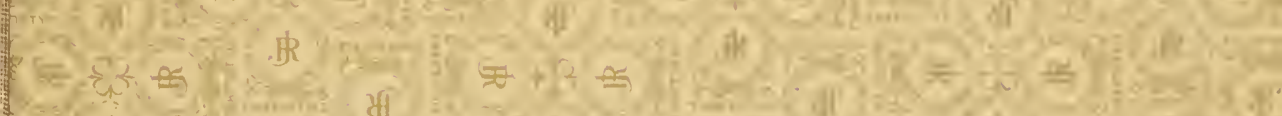

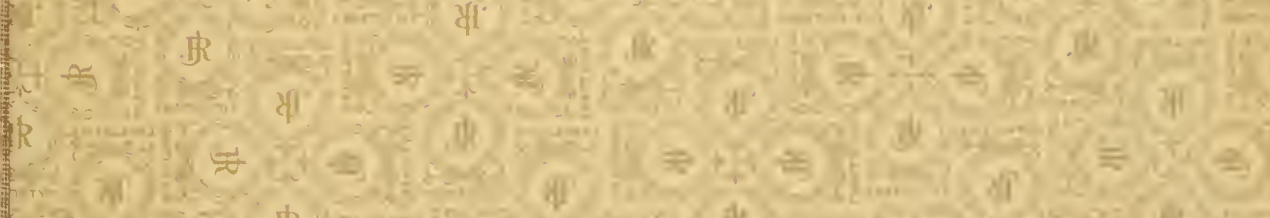
1) R

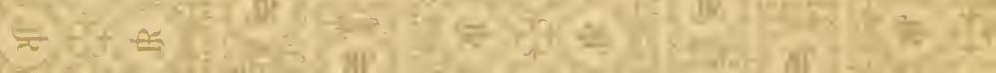


